\title{
Current status and distribution of diurnal raptor species in the south-eastern Anatolia Region, Turkey
}

\author{
Súčasný stav a rozš́renie denných druhov dravých vtákov \\ juhovýchodnej Anatólie, Turecko
}

\author{
Recep KARAKAȘ
}

\begin{abstract}
The status and distribution of diurnal raptor bird species were analysed in the south-eastern part of Turkey based on studies and records between 1994 and 2014. Our information about raptor species is very limited in the south-eastern Anatolia Region. The study showed that of 42 diurnal raptor species listed in Turkey, 37 of these species were found in the studied region; 9 of them are certainly, 4 probably and 1 possibly breeding in the area - according to the breeding criteria of the EBCC - while 17 of them were transitory migrating or wintering birds for the region, and the breeding/migratory status of 6 is unknown. Habitats lost and fragmentation related to agricultural intensification together with pesticide applications are the main hazards threatening wildlife including raptors in the region. So as to increase knowledge on raptors in south-eastern Anatolia and evaluate their populations, a coordinated education and research program is essential.
\end{abstract}

\begin{abstract}
Abstrakt: Stav a rozšírenie denných druhov dravých vtákov v juhovýchodnej časti Turecka boli vyhodnotené na základe publikovaných prác a vlastných pozorovaní z rokov 1994 až 2014. Informácíi o diverzite tejto skupiny je z oblasti juhovýchodnej Anatólie málo. Z výsledkov vyplýva, že zo 42 denných druhov dravých vtákov bolo v regióne zaznamenaných 37 druhov; z toho 9 druhov hniezdičov, 4 pravdepodobných hniezdičov a 1 možný hniezdič - na základe kritérií EBCC, 17 z nich je migrujúcich alebo zimujúcich druhov a hniezdny/migračný status 6 druhov nie je známy. Strata a fragmentácia habitatu súvisiaca s intenzifikáciou pol’nohospodárstva sprevádzaná aplikáciou pesticídov sú hlavným rizikom ohrozujúcim divo žijúce zvieratá vrátane denných dravých vtákov v regióne. Na získanie detailnejších poznatkov o populáciách denných dravcov juhovýchodnej Anatólie je ale potrebná koordinovaná osveta a d’alší výskum.
\end{abstract}

Key words: birds of prey, distribution, ecological changes, south-eastern Anatolia, Turkey.

Recep Karakaş, Dicle University, Science Faculty, Department of Biology, 21280 Diyarbakır, Turkey. E-mail: rkarakas@dicle.edu.tr.

Acknowledgments: I would like to thank Prof. Dr. Ahmet Kiliç and Prof. Dr. Murat Biricik for sharing their records on raptors.

\section{Introduction}

The raptors are excellent bio-indicators of environmental health and widely preferred for monitoring of wildlife and conservation programs (Mac Nally et al. 2004, Chambers 2008). Since raptors are located at the top of the food chains, their population fluctuations provide good information for natural ecosystems (Thiollay 1994, 2006, Herremans \& Herremans-Tonnoeyr 2000). So important information on natural ecosystems could be obtained by monitoring raptor species. Most of the raptors are seriously threatened in Europe (Tucker \& Heath 1994, Birdlife 2004), Asia, Middle East and Africa (Cramp 1998, Ferguson-Lees \& Christie 2001, Mebs \& Schmidt 2006). It is essential therefore to determine the status and distribution of this group in different countries and regions.
Special habitats such as wetlands, mountains, semidesert and steppe areas in the south-eastern Anatolia (SEA) Region together with Tigris and Euphrates River ecosystems make the region important for raptor species in Turkey (Welch 2004, Karakaş 2010, Biricik \& Karakaş 2012). The region has experienced ecological changes mainly related to dams and agricultural regime changes due to GAP (south-eastern Anatolia Project), which is a comprehensive development project together with applications in the region (Welch 2004, Karakaș 2012). Related to the correlation between land-use and agricultural regime changes together with other ecological components, species composition and distribution ranges of raptors in the south-eastern part of Turkey may have changed like other examples in the world (Crick 2004, Huntley et al. 2006). Expansion of agri- 
culture, change in cropping patterns together with pesticide applications, dams and irrigation channels presumably will affect raptor diversity in this part of the country.

The SEA region has rich bird diversity as a consequence of its location and different habitat types. In general, bird diversity in this region is relatively well known as a result of recent publications and monitoring researches (Biricik 1996, Karakaş \& K1lıç 2002, 2004, 2005, Karakaş 2004, Biricik \& Karakaş 2012). However, little is known about diurnal raptor (hereafter raptor) species, and there have been no surveys specially concentrating on this group in this part of the country.

This study is based on main local studies and personal observations during various surveys of the SEA between 1994-2014. The paper aims to present information on raptor species in the SEA region by providing a full list of species, breeding categories, risk status and seasonal occurrence. Additionally it presents information for the main areas that have great importance for the raptors in the region, together with conservation recommendations.

\section{Material and methods}

The SEA region occupies nearly $9 \%$ of Turkey's geographical area and covers $75358 \mathrm{~km}^{2}$ in the south-eastern part of the country (Fig. 1). The region has a typical dry terrestrial climate and a characteristic landscape of lowlands and steppe areas together with mountain areas. In order to determine the distribution of raptor species in SEA, all records of species between 1994-2014 years were taken into account together with Turkey's national bird reports. Based on the main local studies in the region (Biricik 1996, Karakaș \& K1lıç 2002, 2004, 2005, Karakaş 2004, Karakaş \& Biricik 2010, Biricik \& Karakaș 2012) and personal observations during various surveys between 1994-2014, the raptor species diversity is summarized.

Field excursions were carried out in each main area during the related period using binoculars $(10 \times 50)$ and telescope $(20-60 \times 60)$. Point-count and transect line methodology was used. Species identification was carried out in the field and office using standard ornithological literature (Cramp 1998, Mullarney et al. 1999). Breeding status of birds was determined by applying the European Bird Census Council (EBCC) criteria (Hagemeijer \& Blair 1997) to our observations of courtship, behaviour and whether eggs, chicks or nests were found. For the systematic list of birds, the work of Kirwan et al. (1999) was followed.

\section{Results}

This is the first review of the status, distribution and numbers of raptor species populations in the south-eastern part of Turkey. The records of raptor species based on regular and irregular field studies between the years 1994-2014 were evaluated. A total of 31 raptor species have been recorded; 9 of them are certainly, 4 probably and 1 possibly was breeding in the area, according to the breeding criteria of the EBCC, while 17 of them were transitory migrating or wintering birds for the region. Seven species are globally threatened; Neophron percnopterus and Falco cherrug endangered (EN), Aquila clanga and A. heliaca vulnerable (VU), Milvus milvus, Aegypius monachus and Falco vespertinus are near

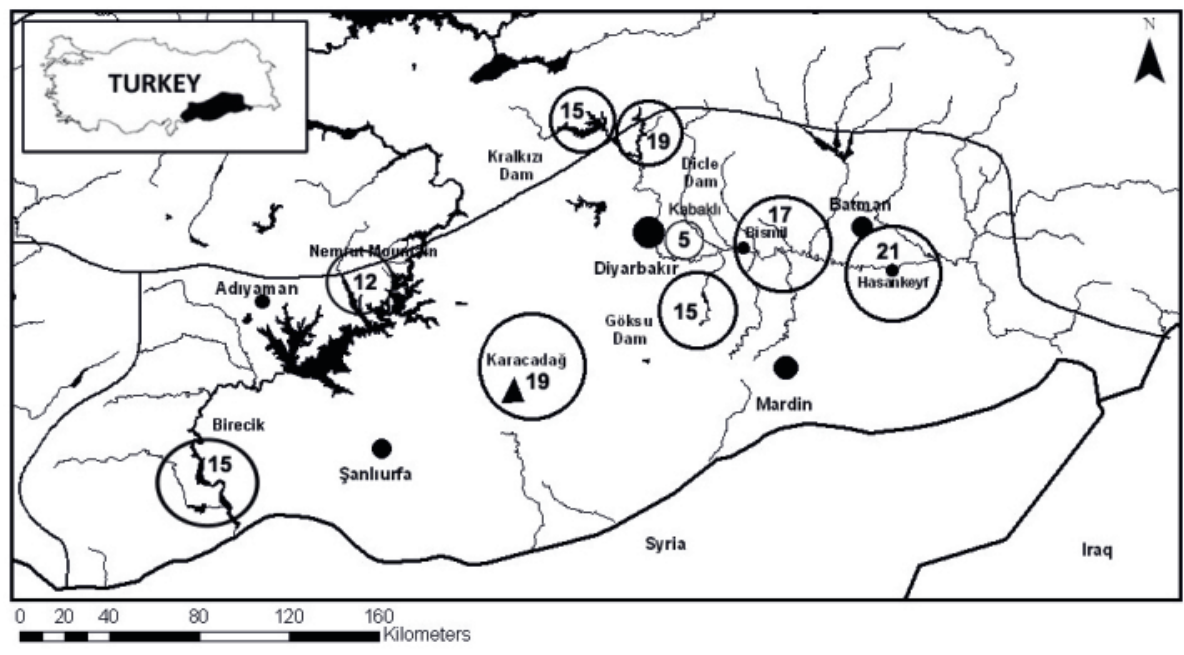

Fig. 1. Map of study area. Numbers in circles indicate raptor diversity in each area.

Obr. 1. Mapa študovaného územia. Hodnoty $v$ krúžkoch udávajú zistený počet druhov dravých vtákov na príslušnom území. 
threatened (NT) according to IUCN criteria (IUCN 2013). In addition, according to Red Data Book for birds of Turkey (Kılıç \& Eken 2004) 15 species (5 EN, 4 NT and 6 VU) are threatened for Turkey apart from least concern species (Tab. 1).

Some locations like Hasankeyf, Karacadağ or Dicle dam in the region provide ideal habitats for many raptor species (Fig. 1). Moreover, the raptor diversity increase during the spring season, mainly in April and May, related to the migration period (Fig. 2).

The evaluations of raptor species recorded in the SEA region between 1994-2014 are presented below:

E u ropea n ho n e y b u z z a rd ( Pernis apivorus)

Records suggest that this species uses the region for spring migration between March-May. Moreover, most of the records relate to May together with the migration peak. This species is common and widespread throughout the region on passage in, especially during spring migration.

B $1 \mathrm{a} \mathrm{c} \mathrm{k-w} \mathrm{i} \mathrm{n} \mathrm{g} \mathrm{e} \mathrm{d} \mathrm{k} \mathrm{i} \mathrm{t} \mathrm{e}$

( Elanus caeruleus)

The occurrence of this species in this part of the country was confirmed during the last decade (Karakaş 2012). Karakaş (2012) emphasized the correlation between the expansion of the species and new conditions arising from ecological changes that have happened in the region, which may enable the species to use new areas. For now, the species can be considered as vagrant for this region and Turkey, together with proven breeding in Şanlıurfa/Bozova (Kirwan et al. 2014), but frequency of records indicates the status of the species will change in the future.

\section{$\mathrm{B} 1 \mathrm{a} \mathrm{ck} \mathrm{kite}(M i l v u s \quad m i g r a n s)$}

Most records suggest that this species uses the area as a transit passage especially in March-April and September. The migration peak is observed between end of March and early April, mainly around the Tigris River valley. Moreover, wintering groups (up to 7,000-8,500 individuals) have been identified in this part of country, mainly around Gaziantep city, between the years 2001-2011 (Biricik \& Karakaş 2011).

$\mathrm{Red} \mathrm{kite}(M i l v u s \quad m i l v u s)$ There is one record of two individuals of this species in the region, on April 6, 2004, between the Bismil-Bat- man. It is a rare / unusual passage migrant species for the region.

E g y p t i a n v u $1 \mathrm{ture}$

( Neophron percnopterus)

This has been recorded in the region between March and September. The species is revealed as a widespread and common summer visitor and breeds in mountainous areas in the region. The presence of the species is dependent on the conservation of suitable feeding and breeding areas in the region. The most suitable breeding and feeding areas are available in the eastern part of the SEA region, mainly around the Hasankeyf area. Loss of suitable habitats and reduced food availability together with human disturbance have affected the population size of this species.

\section{$\mathrm{Griffor} \quad \mathrm{vult} \mathrm{ur}$ e}

( Gyps fulvus)

This has been revealed as a resident breeder or partial migrant species for the region. Records indicate three main areas; Hasankeyf, Karacadağ and Nemrut Mountain.

C i n e re o u s v u $1 \mathrm{t} \mathrm{u} \mathrm{re}$ ( A egypius monachus)

This species is revealed as an uncommon and rare resident breeder for mountain areas, mainly in the eastern part of the SEA region. One record is available for this extremely scarce species in the east of the Hasankeyf area (Karakaş \& Biricik 2012).

$\mathrm{Short}-\mathrm{t}$ o e d $\mathrm{s} n$ a k e e g l e

( Circaetus gallicus)

The species is revealed as transit migratory together with probability of breeding in suitable areas such as Hasankeyf or Siirt. Passage in spring and autumn peaking occurs in April and August respectively.

We s tern mars h harrier

( Circus a eruginosus)

This is a locally resident breeder in suitable areas where especially marshy wetlands with reed cover occur. It has been recorded in different localities during the year, and it is a breeding species in the region mainly around the Bismil plain, Kralkızı dam and Birecik-Karkamış area.

$\mathrm{He} \mathrm{n}$ h a r rier (Circus cyaneus) Although this has been recorded in different localities dur- 


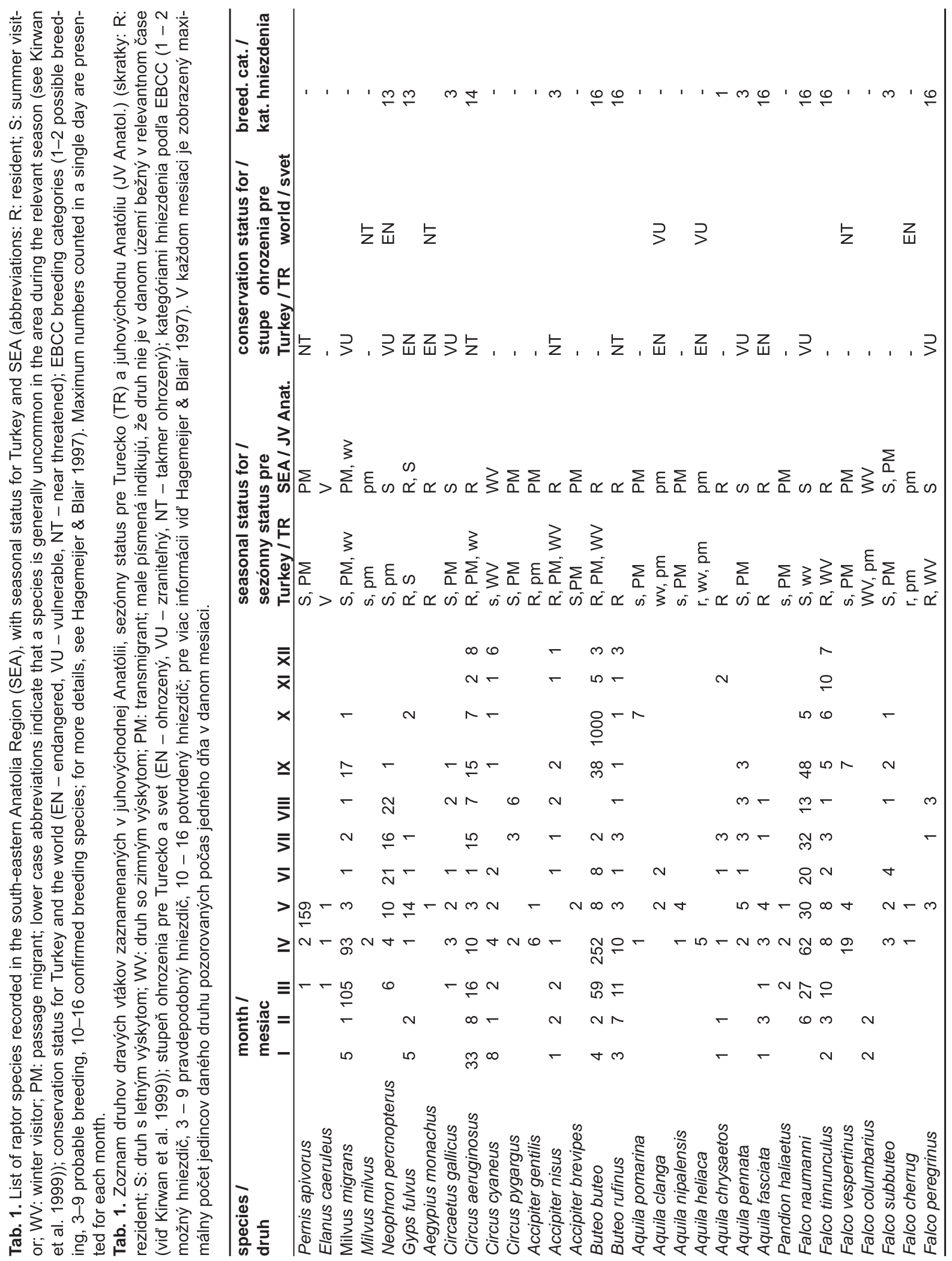


ing the spring/autumn migration and winter periods; it was concluded that the species is a regular winter visitor for the region and it has a widespread distribution in the region.

$\mathrm{Montagu}$ 's harrie r

( Circus pygargus)

This is a widespread and common passage migrant, but there are suitable breeding areas in the region for the species, such as marshy wetlands, damp grasslands and agricultural fields. Most records relate to the Bismil plain, and there are also reports from Hasankeyf, Karacadağ and the Kralkızı dam area.

$\mathrm{Northern}$ go s h a w k

( Accipiter gentilis)

This is revealed as a fairly rare spring migrant, mainly in April. All of the records were made in April except one in May, and it was determined that it uses the area for spring passage. Although there are no records of it in the autumn period, Martins (1989) reported one record in August, maybe of an early migrating individual.

E u r a s i a n s parrow h a w k ( Accipiter nisus)

This is an uncommon local resident species mainly in higher or mountain areas, and probably a breeding species in suitable areas in the region.

L e v a n t s p a r r o w h a w k

( Accipiter brevipes)

One record of two individuals is available in the region (Hasankeyf area) for a species that uses the region during the migration season. So it should be recorded as an uncommon passage migrant for the region.

$\mathrm{C}$ o m mo n b u z z a r d

( $B u t$ e o buteo )

Although recorded the whole year round in different locations in the region, it mainly uses the region during the migration season, and hundreds of individuals have been observed many times. In general, it is widespread and a relatively common passage migrant showing peaks in April and October during spring and autumn migrations respectively. Big flocks are observed mainly around the Tigris River and valley, at Diyarbakır. On the other hand, almost all of the observed individuals during migration belong to Buteo buteo vulpinus subspecies. Moreover, it breeds in higher or mountain areas.

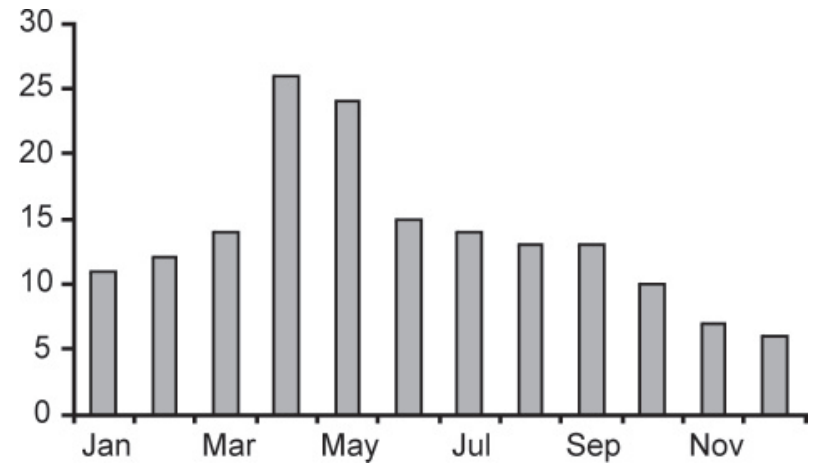

Fig. 2. Distribution of raptor species observed in the southeastern Anatolia for each month.

Obr. 2. Distribúcia pozorovaných druhov dravých vákov $\vee$ juhovýchodnej Anatólii po jednotlivých mesiacoch.

$\mathrm{L}$ o n g - l e g g e d b u z z a r d

( $B$ u t e o rufinus)

This is a local resident species for the region and is recorded during the whole year. It was determined that the species definitely breeds in suitable habitats in the region such as Hasankeyf, Karacadağ, or Nemrut Mountain.

L e s s e r s p o t t e d e a g le

( A quila pomarina)

This is a rare passage migrant for this part of the country. Only two records of the species are available: one record is from Karacadag in April 2001, while the other was reported in the Hasankeyf area in October (Biricik \& Karakaş 2012). Both areas are habitats of mountainous character.

Greater s p ot te d e a g le

( Aquila clanga)

This is an uncommon and rare passage migrant for this part of the country. Two records are available: one from Göksu dam (Karakaş \& Kılıç 2002) while the other was reported in the Karkamıs dam-Birecik area during May 2005.

$\mathrm{St}$ e p p e e a g $1 \mathrm{e}$

( A quila nipalensis)

This migrant species uses the region for spring migration between April-May. It has been reported in the Dicle dam (Karakaş \& Kılıç 2004) and Hasankeyf areas 
(Biricik \& Karakaş 2012). Beaman (1986) reported a sighting at Viranşehir in April 1981. The species is revealed as an uncommon migrant for the region.

Eastern i m e ria 1 e a $\mathrm{g} l \mathrm{e}$

( A quila heliaca)

This species is an uncommon, rare migrant for the SEA region. Although records suggest the species is a transit migratory one, it is possible that it breeds in some higher areas especially in the north and east of the region where there are suitable habitats for its breeding (Welch 2004).

$\mathrm{G}$ o $1 \mathrm{~d}$ e $\mathrm{n}$ e a $\mathrm{g} 1 \mathrm{e}$

( A quila chrysaetos)

This can be seen in widespread and moderate numbers in mountain areas as a local resident. It probably breeds in suitable mountain areas such as Karacadağ or Hasankeyf in the region.

B o o t e d e a g $1 \mathrm{e}$

( A quila pennata)

Widespread and not uncommon summer visitor, principally to the eastern part of the region, where it has suitable areas for breeding.

B o n e $11 \mathrm{i}^{\prime} \mathrm{s}$ e a g $1 \mathrm{e}$

( Hi era a e t us fasciata)

This species is a local and scarce resident breeding in the region. Its records from Halfeti and Birecik between May and July are available (Eames 1990, Martins 1989, Kirwan \& Martins 1994). Kilıç et al. (2003) reported a breeding pair near Hasankeyf. It is possible to conclude that it is a local resident species, and definitely breeds in the region. Only three breeding pairs have been known in the region, but it seems that the breeding ground near Halfeti by the Euphrates river bank is not used any more due to the increased level of water in the Birecik Reservoir. Moreover, the breeding areas around Hasankeyf are threatened by the Ilisu dam project (Biricik \& Karakaş 2012).

$\mathrm{W}$ e $\mathrm{st}$ e r $\mathrm{n}$ o s p r e y

( Pandion haliaetus)

Karakaş \& Kilıç (2002) reported three sightings by Diyarbakır-Çınar Göksu dam; two individuals in April and one individual in May 1999. In addition, the species has been observed in mid-March in the region, at least for the last four years. It was concluded that the species uses the area during the spring migration season.

$\mathrm{L}$ e s s e r k e s t r e 1

( Falco na $\cos$ a $n i$ )

This species is a regular summer migrant for SEA, and breeds in some localities. Their records are available from the end of February to the beginning of October. One of the most numerous populations for the SEA region, breeding in the Hasankeyf area which is threatened by the Ilisu dam project. Some colonies have disappeared during the last decade, such as in the Karacadağ area. Loss of steppe areas and increased use of pesticides threaten the species in the region.

$\mathrm{Com}$ o $\mathrm{n}$ k e s t r e 1

( Falco tinnunculus)

The most common and widespread resident raptor breeding in the SEA region, and it has been recorded in all of the main areas including city centres. Found in a wide variety of habitats from wetlands to city centres.

$\mathrm{R}$ e d - f o o t e d fa $1 \mathrm{con}$

( Falco vespertinus)

It is recorded during migration periods in large areas of the region, during April-May and September. The migration peak is observed in mid-April. It was concluded that it has used the area for the spring and autumn migration periods.

M e r lin (Falco columbarius) This mainly prefers open areas, and has been observed during winter while flying for foraging. It has been recorded in the region during January - February and it is revealed as a winter visitor for SEA region.

E u r a s i a h o b b y

( Falco subbuteo )

This has been recorded at the Kralkızı and Dicle dams in May and September, as well as being recorded in October at Hasankeyf and its surroundings. Moreover, the species was observed at Kamboğazı / Nemrut Mountain during June and August in 2010, including at least two juveniles. The records suggest that the species uses the area during the spring and autumn transition periods. There is also the possibility of breeding by the species in suitable areas like Hasankeyf and Nemrut Mountain.

$\mathrm{S}$ a k e r f a l c o n ( Falco cherrug) Two records of this species are available for the SEA 
region apart from literature records, as of one individual each from the Göksu dam and Kabaklı Reservoir. The species could be revealed as an uncommon passage migrant for the region, using the area during transition periods. There is the possibility of breeding in some higher arid mountain areas, mainly the extreme eastern part of the region. Moreover, the species uses open steppe areas close to these mountains.

$\mathrm{P}$ e r e grine fa $1 \mathrm{con}$

( Falco peregrinus)

This species uses the region mainly during transition periods together with two possible breeding areas in this part of the country (Hasankeyf, Karacadağ). Breeding was proven in one area by two active nests together with at least two chicks in the Hasankeyf area. It is reported from around Birecik in July and August. Records in May-September are also available, and it is likely to breed in the region too.

\section{Discussion}

I have reviewed and summarized published accounts, together with additional records based on personal observations on raptor diversity gathered throughout SEA, Turkey. The status and distribution of 31 raptor species occurring in the region have been determined and reliably recorded. When the existence of 40 (Kirwan et al. 1999) or 42 species (Kirwan et al. 2008) of raptors together with vagrant species is taken into account for the whole of Turkey, the importance of the region for raptor species is understood better. Nevertheless, there are 6 species that were not identified during our field studies reported from the region; Gypaetus barbatus, Circus macrorus, Falco eleonorae, Falco concolor, Falco biarmicus and Falco pelegrinoides (Kumerloeve 1963, 1967, Vielliard 1968, Murphy 1984, Beaman 1986, Martins 1989, Eames 1990, Kirwan \& Martins 1994, 2000, Kirwan et al. 2003, Welch 2004). From a review of the current studies and available literature together with data on bird diversity, it is clear that at least 37 of the 40 or 42 raptors assessed occur in this part of Turkey. In this way, the importance of the region for the mentioned group could be understood easily.

Most of the raptors are seriously threatened and require conservation in many countries including Turkey (Tucker \& Heath 1994, Birdlife 2004, IUCN 2013). Information on habitat-related threats to raptors both in the SEA region and Turkey as a whole is very limited. However, there have been some main studies (Tucker \&
Heath 1994, Birdlife 2004) in the Palaearctic zone that indicate that conversion of steppes to agricultural arable fields is unsuitable for many raptors, at least steppe raptors such as the steppe eagle (Aquila nipalensis), imperial eagle (Aquila heliaca), or saker falcon (Falco cherrug) (Sanchez-Zapata et al. 2003, Galushin 2004). Intensification of agriculture together with monoculture fields and high levels of pesticide use threaten many raptor species because they result in reduced prey availability in the region. Although there is a lack of data for the effects of agricultural expansion on raptors, it is thought that such changes may be having significant impacts on species that need open steppes and grasslands for foraging. Many raptors suffer from habitat destruction through disruption of the natural structure and fragmenting of the areas, leaving insufficient space for home ranges or foraging areas. In addition, it has been reported that some raptor species have been trapped for hunting in some parts of Turkey (Turan 1996, 2005).

The huge increase in irrigated fields has provided different ecological conditions which have resulted in alteration of species composition over large areas of SEA region (Welch 2004, Biricik \& Karakaş 2012). It is estimated that the existing alteration process in the region related to GAP in the last few decades will presumably affect the raptors that are at the top of the food chain in the long term. Agricultural intensification, habitat loss, reduction in food availability and disturbance are considered as the most important threats to the raptor population of the SEA region. In Turkey, agricultural pesticides, carcass poisoning and hunting are revealed as major threats for raptors (Turan 2005, Biricik \& Karakaş 2011).

Consequently, it is possible to indicate that the region is extremely rich in raptors. Despite all raptors being legally protected in Turkey, illegal hunting is still a problem. Substantial changes have occurred in the south-eastern part of Turkey in recent decades, mainly related to habitat loss as a result of big dam projects and agricultural intensification. It could be stated that habitat loss and fragmentation related to agricultural intensification are common hazards threatening wildlife including raptors in this region. The occurrence of raptor species is often related to the availability of suitable habitats including food and nesting areas, like other birds. In addition, habitat alterations may also result in species composition changes in the future. Due to their position at the top of the food chain, raptors respond rapidly to threats and changing environmental conditions. So by 
monitoring this group valuable information could be obtained about the ecosystem.

For the conservation of raptors large national parks may be important alternatives for viable populations of some raptors that are globally threatened. The permanence of habitat heterogeneity in the region is a key factor for the conservation of raptor species, including endangered ones. Moreover, so as to increase knowledge on raptors in south-eastern Anatolia and evaluate their populations, a coordinated education and research program is essential.

\section{References}

Beaman M 1986: Turkey Bird Report 1976-81. Sandgrouse 8: 1-41.

BirdLife International 2004: Birds in the European Union: a status assessment. BirdLife International, Wageningen, The Netherlands, 160.

Biricik M 1996: Birds of Kabaklı Reservoir, Diyarbakır. Turkish Journal of Zoology 20: 155-160.

Biricik M \& Karakaş R 2011: Black kites (Milvus migrans) winter in southeastern Anatolia, Turkey. Journal of Raptor Research 45: 370-373. DOI: 10.3356/JRR-10-109.1.

Biricik M \& Karakaş R 2012: Birds of Hasankeyf (south-eastern Anatolia, Turkey) under the threat of a big dam project. Natural Areas Journal 32(1): 96-105. DOI: 10.3375/043.032.0111.

Chambers SA 2008: Birds as environmental indicators: review of literature. Parks Victoria Technical Series No. 55. Parks Victoria, Melbourne, 48

Cramp S 1998: The complete birds of the Western Palearctic. Oxford University Press. CD ROMs.

Crick HQP 2004: The impact of climate change on birds. Ibis 146 (Suppl. 1): 48-56. DOI: 10.1111/j.1474-919X.2004.00327.x

Eames J 1990: Selected Bird Observations from Turkey: Spring and Summer 1987. OSME Bulletin 23: 6-13.

Ferguson-Lees J \& Christie DA 2001: Raptors of the World. Christopher Helm, London, 320.

Galushin VM 2004: Status of Saker in Russia and Eastern Europe. Falco 24: 3-8.

Hagemeijer EJM \& Blair MJ (eds) 1997: The EBCC Atlas of European breeding birds; their distribution and abundance. Poyser. London, 903.

Herremans M \& Herremans-Tonnoeyr D 2000: Land use and the conservation status of raptors in Botswana. Biological Conservation 94: 31-41. DOI: 10.1016/S0006-3207(99)00166-4.
Huntley B, Collingham YC, Green RE, Hilton GM, Rahbek C \& Willis SG 2006: Potential impacts of climate change upon geographical distributions of birds. Ibis 148: 8-28. DOI: 10.1111/j.1474919X.2006.00523.x.

IUCN 2013: IUCN Red list of threatened species. Version 2013.2. Retrieved on June 6, 2014, from www.iucnredlist.org.

Karakaş R 2004: Contribution to the knowledge of avifauna of Karacadağ, south-eastern Anatolia (Turkey). Acrocephalus 25(122): 139-148.

Karakaş R 2010: Bird diversity in Bismil plain IBA's with new records for south-eastern Anatolia, Turkey. European Journal of Wildlife Research 56: 471-480. DOI: 10.1007/s 10344-009-0336-6.

Karakaş R \& Biricik M 2010: Adıyaman Nemrut Dağ1 ve Çevresinin Avifaunası Araştırmasında İlk Bulgular [First results of the avifauna research in Adiyaman Nemrut Mountain and its environment], 807-808. In: Şen A (ed), 20th National Biology Congress Abstract Book. National Biology Congress, 21-25 June 2010, Denizli, Türkiye, 1110.

Karakaș R 2012: Does black-winged kite Elanus caeruleus (Desfontaines, 1789) have an expansion in its range in Turkey? Acta Zoologica Bulgarica 64(2): 209-214.

Karakaş R \& Kılıç A 2002: Birds of Göksu dam (Diyarbakir) and new records in south-east Turkey. Sandgrouse 24(1): 38-43.

Karakaş R \& Kilıç A 2004: The birds of Dicle dam (Diyarbakır). Turkish Journal of Zoology 28: 301-308.

Karakaş R \& Kılıç A 2005: The birds of Kralkızı dam (Diyarbakır), southeast Turkey. Sandgrouse 27(2): 139-146.

Kasparek M \& Bilgin CC 1996: Kuşlar (Aves), 27-87. In: Kence A \& Bilgin CC (eds) Türkiye Omurgalılar Tür Listesi [Species list for vertebrates of Turkey]. Tübitak, Ankara, 183. [In Turkish]

Kılıç A, Karakaş R \& Biricik M 2003: Observations on a newly detected breeding site of Bonelli's Eagle, Hieraaetus fasciatus, in south-eastern Anatolia. Zoology in the Middle East 30: 37-41.

Kılıç DT \& Eken G 2004: Türkiye'nin Önemli Kuş Alanlar1-2004 Güncellemesi [Turkey's Important Bird Areas - 2004 Update] Doğa Derneği, Ankara, Türkiye, 231. [In Turkish]

Kirwan GM \& Martins RP 1994: Turkey bird report 1987-91. Sandgrouse 16(2): 76-117.

Kirwan GM, Martins RP, Eken G \& Davidson P 1999: A 
checklist of the birds of Turkey. Sandgrouse, Suppl. 1: $1-32$.

Kirwan GM \& Martins RP 2000: Turkey bird report 1992-1996. Sandgrouse 22(1): 13-35.

Kirwan GM, Özen M, Kurt B \& Martins RP 2003: Turkey Bird Report 1997-2001. Sandgrouse 25: 8-31.

Kirwan GM, Boyla K, Castell P, Demirci B, Özen M, Welch H \& Marlow T 2008: The birds of Turkey. Christopher Helm, London, 512.

Kirwan GM, Özen M, Erturhan M \& Atahan A 2014: Turkey Bird Report 2007-2011. Sandgrouse 36: 146-175.

Kumerloeve H 1963: Zur Kenntnis der Avifauna Kleinasiens. Bonner zoologische Beiträge 12: $1-318$.

Kumerloeve H 1967: Doğu ve Kuzeydoğu Küçük Asya'nın Kuşları [Birds of East and Northeast Asia Minor]. İstanbul Üniversitesi Fen Fakültesi Mecmuası 32 (3-4): 79-213. [In Turkish with German summary]

Mac Nally R, Ellis M \& Barret G 2004: Avian biodiversity monitoring in Australian rangelands. Austral Ecology 29: 93-99. DOI: 10.1111/j.144 2-9993.2004.01352.x.

Martins RP 1989: Turkey bird report 1982-86. Sandgrouse 11: 1-41.

Mebs T \& Schmidt D 2006: Die Greifvögel Europas, Nordafrikas und Vorderasiens Biologie, Kennzeichen, Bestände. Franckh-Kosmos Verlags Stuttgart, 495.

Mullarney K, Svensson L, Grant PJ \& Zetterström D 1999: Collins bird guide. Harper Collins, London, 385.
Murphy C 1984: Recent trips to eastern Turkey 1983. OSME Bulletin 13: 8-2.

Sánchez-Zapata JA, Carrete M, Gravilov A, Sklyarenko S, Ceballos O, Donázar JA \& Hiraldo F 2003: Land use changes and raptor conservation in steppe habitats of eastern Kazakhstan. Biological Conservation 111: 71-77. DOI: 10.1016/S0006-3207(02)00251-3.

Thiollay JM 1994: Accipitridae (hawks and eagles) 52-105. In: del Hoyo J, Elliott A \& Sargatal J (eds), Handbook of the birds of the world. Vol. 2: New World vultures to guineafowl, Lynx Edicions, Barcelona, 638.

Thiollay JM 2006: The decline of raptors in West Africa: long-term assessment, human pressure and role of protected areas. Ibis 148: 240-254. DOI: 10.1111/j.1474-919X.2006.00531.x.

Tucker GM \& Heath MF 1994: Birds in Europe: their conservation status. Birdlife International, Cambridge, 600 .

Turan L 1996: Yırtıcı Kuş Türleri ile Avcılık [Types of hunting with birds of prey]. Hacettepe Üniversitesi Eğitim Fakültesi Dergisi 12: 207-210. [In Turkish with English summary]

Turan L 2005: The status of diurnal birds of prey in Turkey. Journal of Raptor Research 39: 36-54.

Vielliard J 1968: Türkiye'de Bir Ornitolojik Gezinin Neticeleri [Results of a Ornithological trip in Turkey]. İstanbul Üniversitesi Fen Fakültesi Mecmuasi, Seri B 33 (3-4): 67-170. [In Turkish]

Welch HJ (ed) 2004: GAP biodiversity research project 2001-2003. Final report. DHKD (Doğal Hayatı Koruma Derneği). İstanbul, Türkiye, 145. 